\title{
The Development of Optimal Cryopreservation Media For Longspine Scraper (Capoeta trutta) Sperm
}

\author{
Erdinç Şahinöz ${ }^{1}$, Zafer Doğu ${ }^{1 *}$, Faruk Aral ${ }^{2}$ \\ ${ }^{I}$ Department of Fisheries and Aquaculture, Bozova Vocational High School, Harran University, 63850 Şanliurfa, Turkey \\ ${ }^{2}$ Department of Reproduction and Artificial Insemination, Bor Vocational High School, Niğde Ömer Halisdemir University, 51700 Niğde, Turkey.
}

\section{A R T I C LE IN F O}

\section{Research Article}

Received 21 December 2017

Accepted 27 February 2018

Keywords:

Capoeta trutta

Longspine scraper

Sperm

Cryopreservation

\begin{abstract}
A B S T R A C T
This study is performed to determine some of sperm quality after applying freezing / thawing process. Thus, the aim of this study is to examine different cryprotective agents with additives in terms of their effects at different $\mathrm{pH}$ on the cryopreservation process of longspine scraper (Capoeta trutta). The present study, twelve media were prepared by mixing three different cryoprotectants (dimethyl sulfoxide (DMSO, $\left(\mathrm{CH}_{3}\right)_{2} \mathrm{SO}$ ); methanol $\left(\mathrm{CH}_{3} \mathrm{OH}\right)$; methyl glycol (MG, $\left.\mathrm{CH}_{3} \mathrm{O}\left(\mathrm{CH}_{2}\right)_{2} \mathrm{OH}\right)$ ) with an extenders (glucose) at four different $\mathrm{pH}(7.2,7.6,8.0$ and 8.4) for longspine scraper semen. Considering the findings from the examination (The motility rate after thawing process and duration of motility obtained in DMSO as $81 \%$ and $20 \mathrm{~min}$, in methanol as $73 \%$ and $12 \mathrm{~min}$, in methyl glycol as $60 \%$ and $15 \mathrm{~min}$.), we can conclude that the DMSO is the best freezing media in order to create new essays in cryopreservation for sperm of Capoeta trutta in the future.
\end{abstract}

\footnotetext{
*Corresponding Author:

E-mail: zaferdogu@harran.edu.tr
}

DOI: https://doi.org/10.24925/turjaf.v6i3.380-386.1766

\section{Introduction}

There are some dominant fish species in Atatürk Dam Lake and longspine scraper is one of them. It belongs to the Cyprinideae that has a wide distribution in both Euphrates and Tigris basins, natural and artificial lakes in Mesopotamia for thousands of years (Özdemir, 1983; Polat, 1987; Ünlü, 1991; Şevik, 1993). Since longspine scraper is one of those species which are usually fished in the abovementioned basin is very important in terms of the economy of the region as being caught for commercial fishing and also for the fishing as a sport. Using liquid nitrogen for storing the fish sperm becomes successful and thus is being used for more than 200 species (Brown and Brown, 2000), although this technique is reported as successful, the protocol using for applying liquid nitrogen differs as per species. For Cyprinidae, semen cryopreservation has been examined in many species such as the common carp Cyprinus carpio (Kurokura et al., 1984; Koldras and Bieniarz, 1987; Babiak et al., 1995) in the asp, Aspius aspius (Babiak and Glogowski, 1998); in the zebra fish, tawes carp-Puntius gonionotus, Labeo rohita, grass carp-Ctenopharyngodon idella, bighead carp-Aristichthys nobilis) (Withler, 1982).Protocols for cryopreservation of semen has been improved for also species of cypriniform such as the razorback sucker, the curimbata, Xyrauchen texanus (Tiersch et al., 1998); Prochilodus scrofa; and the dourado, Salminus maxillosus (Coser et al., 1984). It is known that the composition of additives, concentration of crypotectant and method of freezing could affect the success of cryopreservation (Sansone et al., 2002; DeGraaf and Berlinsky, 2004). Using ethylene glycol (EG), methanol, glycerol and dimethyl sulfoxide (DMSO) or dimethyl acetamide (DMA) for the cryopreserving the common carp sperm could affect the sperm motility after thawing process and/or hatching process or fertilization (Lahnsteiner et al., 2000; Linhart et al., 2000). Besides, it was observed that using DMSO in equilibration could cause damaging effects to carp sperm (Lubzens et al., 1997), and also other comparative DMSO studies revealed that methanol, glycerol and DMA has a better suitability for freezing the carp sperm (Lakra and Krichna 1997). Although, there has been considerable research on semen preservation in teleosts (Kurokura et al., 1984; Cognie et al., 1989; Zhang and Liu, 1991 Linhart et al., 1988), there is no available data about the $C$. trutta sperm and its cryopreservation. 
Numerous studies have been carried out to determine various biological properties of $C$. trutta. It has been reported that it reaches sexual maturity at 2-3 years of age and the breeding seasons lasts from the beginning of April to the end of August (Şevik, 1995; Yapalak et al., 1997; Bozkurt et al., 1999; Kalkan, 2008; Duman, 2004; Oymak et al., 2008; Düşükcan and Çalta 2012; Canpolat and Calta, 2013; Eroğlu and Şen, 2017). In order to manage and conserve the species, it is critical to have the knowledge of reproductive biology and physiology. This also allows the prevention of species from extinction and thus, males could be utilized in natural and artificial reproductive programmes (Wildt et al., 2010). High level of prolificacy could be reached if the artificial reproduction methods of all Cyprinid species are well applied. So, in this study, the longspine scraper was taken as the sample model for making a research regarding the reproduction of fish. Mostly, the immobility of fish spermatozoa is seen in the seminal tract and the motility of sperm is commenced by means of hyposmotic environment in fish species living in fresh water (Morisawa and Suzuki, 1980). In previous studies, Doğu et al. (2015) reported the values of $C$. trutta that the mean values of semen $(\mu \mathrm{l})$, motility $(\%)$, motility duration (sec), density $\left(\times 10^{9} / \mathrm{ml}\right)$ and $\mathrm{pH}$ were $150.71 \pm 6.91 ; 67.74 \pm 1.01$; $65.74 \pm 1.40 ; \quad 19.68 \pm 0.74$ and $7.22 \pm 0.01$ respectively. Özgür and Gürçay (2016), was stated that the motile activity of spermatozoa was evaluated to some parameters characterizing sperm movement which has known that; VSL $(\mu \mathrm{m} / \mathrm{s})$; straight line velocity, VCL $(\mu \mathrm{m} / \mathrm{s})$; curvilinear velocity, VAP $(\mu \mathrm{m} / \mathrm{s})$; the angular path velocity, STR (VSL/VAP)(\%); straightness, LIN (VSL/VCL) $(\%)$, the linearity, BCF $(\mathrm{Hz})$; beat crass frequency, ALH $(\mu \mathrm{m})$, amplitude of lateral head displacement and MAD; mean angular displacement in spermatoza of Capoeta trutta. According to results, motility parameters were determined to 13.09 , 74.01, $29.88,42.44,21.42,8.81,15.56$ and 0.02 , respectively.

As well as several factors could affect the motility of sperm such as; osmolality, $\mathrm{pH}$ and temperature (Alavi and Cosson, 2006; Alavi et al., 2006). It is necessary to make and analyze studies which are made on the effects of those above mentioned factors to set up a standard activating agent and immobilizing media in order to improve those techniques using during fertilization and preservation process (Alavi et al., 2009). those parameters of the swimming medium such as ion concentration $\left(\mathrm{K}^{+}\right.$, $\mathrm{Na}^{+}, \mathrm{Ca}^{2+}, \mathrm{Mg}^{2+}$ ), osmotic level, $\mathrm{pH}$ and dilution rate could affect the duration of motility in fish spermatozoa (Alavi and Cosson, 2005.) $\mathrm{pH}$ is known as the most activating factor for sperm of fish species (Stoss, 1983). The fertilizing capacity of the sperm could also be affected by the the activating solution $\mathrm{pH}$. (Billard et al., 1995). Ideal motility rate in sperm of Cyprinus carpio was observed at pH 7.0 and 8.0 (Cosson et al., 1991).

Purpose of this study was testing three different types of cryoprotectant agents considering their effects, such as; dimethyl sulfoxide (DMSO, $\left.\left(\mathrm{CH}_{3}\right)_{2} \mathrm{SO}\right)$; methanol $\left(\mathrm{CH}_{3} \mathrm{OH}\right)$; methylglycol (MG, $\left.\left.\mathrm{CH}_{3} \mathrm{O} \quad\left(\mathrm{CH}_{2}\right)_{2} \mathrm{OH}\right)\right)$ combined with an extenders at four different $\mathrm{pH}(7.2,7.6$, 8.0 and 8.4) on the cryopreservation process of longspine scraper-C. trutta sperm.

\section{Material Methods}

This study was carried out on the species called longspine scraper living in Atatürk Dam Lake (37²3' 9 "03"'N, 38०34'38"05"'3E) by the Department of Fisheries of Bozova Vocational School for Higher Education of Harran University. During the study, it was captured in the middle of the spawning season on June 2016. The longspine scrapers $(n=10)$ were fished by using gill nets $(42 \mathrm{~mm} \times 42 \mathrm{~mm}-55 \mathrm{~mm} \times 55 \mathrm{~mm})$ at Atatürk Dam Lake and those fish which were selected randomly, were kept under the temperature of natural lakewater $\left(23.00 \pm 4.80^{\circ} \mathrm{C}\right)$ with oxygen rate $(8.44-9.28 \mathrm{mg} / \mathrm{l}), \mathrm{pH}$ (8.05-8.322). YSI Environmental (YSI 85) was used to measure those parameters of the areas from where samples were taken were measured by using YSI Environmental (YSI 85) in terms of physico-chemical features. Fiberglass tanks were filled with lake water and were used to take those samples to the laboratory. Several scales were used to determine the age of fish by using a stereo microscope (Nikon SMZ 2T stereo) Captive longspine scraper size ranged between 260.00 and $390.00 \mathrm{~g}$ (mean $335.00 \pm 27.23 \mathrm{~g}$ ) in body weight and 30.00 and $34.00 \mathrm{~cm}$ (mean $32.80 \pm 0.93 \mathrm{~cm}$ ) in total length. Fish age ranges from 5 to 8 years old. Samples taken from milt were put into tubes in order to collect sperms and a gentle manual pressure to abdomen was applied. After the sperm collection process, those tubes which contain sperm were put into a polystyrene box filled with crushed ice $\left(5 \pm 2{ }^{\circ} \mathrm{C}\right)$. Sperm samples were carefully protected from contamination due to water, urine or faeces.

\section{Spermatozoa Motility, Osmolality and Concentration}

After those sperm samples were collected, a light microscope with the magnification feature $\times 400$ (with the brand name of (Nikon SMZ 2Tstereo) was used to observe samples of which $5 \mu \mathrm{L}$ was examined on a glass slide. Since it is required to obtain an immotile fish sperm to be examined in seminal plasma, when sperm motility occurred, contamination in water or any urine involvement was considered as the cause of motility and thus, the sample was not used and eliminated from the study. In immotile samples ( $n=10$ males), the motility of sperm was activated by using $50 \mathrm{mM} \mathrm{NaCl}(\mathrm{pH} 8.0)$, and for the activating agent, this triggered sperm mobility was used and light microscobe was used for estimating it subjectively. (Linhart et al., 2003). In the subsequent analyses, it is required to use the samples which has only samples at least $80 \%$ motile sperm. The ratio of motility and immobility in terms of cells, was estimated in order to the proportion of motile and non-motile cell was estimated in order to determine the motility rate visually as being in tree times more. The rate of motility was estimated the proportion of progressive motile spermatozoa in a microscope field and it can be determined the motility rate visually as being in tree times in different field in a microscope. The duration of sperm motility was subjectively evaluated as the time elapsed from activation until $5 \%$ of the spermatozoa maintained forward swimming activity. The osmolality of sperm (approximately $500 \mu \mathrm{L}$ ) from each male was measured at room temperature cryoscopically (Osmometer 3250, Advanced Instruments INC, Massachusetts, USA). 
Hemocytometric method was used to determine Spermatozoa concentration which was expressed as number of spermatozoa $\times 10^{9} / \mathrm{ml}$. Firstly, in order to dilute the milt in a $1.5-\mathrm{ml}$ test tube, a distilled well water in the amount of $9990 \mu \mathrm{l}$ was mixed with milt in the amount of $10 \mu \mathrm{l}$ and then the dilution was mixed by using a vortex mixer. The result was obtained after the number of milt cells was counted in a known haemacytometer volume (Thoma chamber, American Opticals, Buffalo, NY).

Extender Composition, Osmolality and Cryoprotectants

In this study, twelve freezing media, including different combinations of three cryoprotectants and an additive at four different $\mathrm{pH}$ were used (Table 1). After the sperm collected and exanimate, it was cooled and diluted at $4^{\circ} \mathrm{C}$. $350 \mathrm{mM}$ glucose (Merck-108337 Chemical Corp) was used as extender. Osmolality of the extenders were measured and set with osmometer as $325 \mathrm{mOsm} / \mathrm{kg}$ cryoscopically (Osmometer 3250, Advanced Instruments INC, Massachusetts, USA). Then, extenders were adjusted to four different $\mathrm{pH}$ values using with $\mathrm{HCl}$ or deiyonized water as: 7.2, 7.6, 8.0 and 8.4 respectively. After that, each extenders were mixed with each cryoprotectants (dimethyl sulfoxide (DMSO, $\left(\mathrm{CH}_{3}\right)_{2} \mathrm{SO}$ ) (Merck-102953); methanol $\left(\mathrm{CH}_{3} \mathrm{OH}\right)$ (Merck-106008); methylglycol ( $\left.\mathrm{MG}, \mathrm{CH}_{3} \mathrm{O}\left(\mathrm{CH}_{2}\right)_{2} \mathrm{OH}\right)$ (Sigma-324558).

Sperm Cryopreservation and Post-Thaw Sperm Analysis

Sperm samples, which were taken from each male, were diluted in each medium with the ratio of 1:5 (sperm: total volume) $(10$ males $\times 12$ media). After the dilution process; samples were examined under light microscope and it was tried to confirm if the initiation of sperm motility would be prevented by all additive-cryoprotectant combinations or not. The percentage of the motile sperm could be annotated if the motility rate was observed. In order to obtain the optimum proportion including $80 \%$ additives, $10 \%$ cryoprotectants and $10 \%$ sperm, those sperm samples which were taken from 10 males, loaded in freezing medium and they were equilibrated in crushed ice $\left(4 \pm 2^{\circ} \mathrm{C}\right)$ for $30 \mathrm{~min}$. Before equilibration, sperm samples were diluted into $0.5-\mathrm{mL}$ straws $(n=12$ media $\times$ 10 males $\times 3$ copies of straws) were used to dilute the sperm samples and then they were sealed by using with a metallic globule, at room temperature. A nitrogen vapor tank was used in order to freeze straws (Air LiquideDMC, Parc Gustave Eiffel, Gutenberg, France) at approximately $-110^{\circ} \mathrm{C}$ and then those frozen straws were kept in liquid nitrogen (M.V.E. Millenium, XC 20, Chart, MN, USA). After 7 days, samples were thawed for $10 \mathrm{~s}$ by using a water bath at $35^{\circ} \mathrm{C}$ (Maria et al, 2006) and motility rate after the abovementioned thawing process (as percentage of motile sperm) and the duration of motility were immediately estimated (as described for fresh sperm).

\section{Statistical Analysis}

The mean was \pm SD and expressed as values used in this analysis. SPSS program version 14.0 was used to perform statistical analyses. Univariate analysis was used in order to test the data for normal distribution and Tukey's post hoc test was made after ANOVA was being used for significant differences. The significance level was kept at $5 \%(\mathrm{P}<0.05)$ for all statistical tests.

Table1 Twelve freezing media, comprising combinations of cryoprotectants and extenders at different $\mathrm{pH}$ used in the experiment

\begin{tabular}{|c|c|c|c|}
\hline No & Extender & $\mathrm{pH}$ & Cryoprotectant \\
\hline 1 & 0.3 M Glucose & 7.2 & DMSO $\% 10$ \\
\hline 2 & 0.3 M Glucose & 7.2 & Methanol \%10 \\
\hline 3 & 0.3 M Glucose & 7.2 & MG \%10 \\
\hline 4 & 0.3 M Glucose & 7.6 & DMSO $\% 10$ \\
\hline 5 & 0.3 M Glucose & 7.6 & Methanol \%10 \\
\hline 6 & $0.3 \mathrm{M}$ Glucose & 7.6 & MG \%10 \\
\hline 7 & $0.3 \mathrm{M}$ Glucose & 8.0 & DMSO $\% 10$ \\
\hline 8 & 0.3 M Glucose & 8.0 & Methanol $\% 10$ \\
\hline 9 & 0.3 M Glucose & 8.0 & MG \%10 \\
\hline 10 & 0.3 M Glucose & 8.4 & DMSO $\% 10$ \\
\hline 11 & 0.3 M Glucose & 8.4 & Methanol \%10 \\
\hline 12 & $0.3 \mathrm{M}$ Glucose & 8.4 & MG $\% 10$ \\
\hline
\end{tabular}

DMSO: Dimethyl Sulfoxide; MG: Methylglycol

\section{Results}

Age groups of 10 C. trutta specimens from Atatürk Dam Lake ranged from 2 to 3 . Fresh sperm, which were taken from 10 male, were processed in this research and included a mean of $85.00 \pm 3.53 \%$ spermatozoa motility rate, duration of motility $365.00 \pm 9.00 \mathrm{~s}$, spermatozoa volume of $157.50 \pm 30.65 \mu 1,7.69 \pm 2.83 \times 10^{9}$ spermatozoa $\mathrm{ml}^{-1}$ and 294.75 $\pm 3.47 \mathrm{mOsmol} \mathrm{kg}^{-1}$ (Table2). On Table 3, the motility rate of sperm which were cryopreserved in twelve freezing media after the thawing process is shown. The diluent $\mathrm{pH}$ has a significant effect on motility rate in all cryoprotectants. All sperm samples which were cryopreserved using DMSO (81.25 $\pm 3.21 \%)$ resulted with greater motility rates compared with methanol $(73.75 \pm 3.21 \%)$ and methyl glycol (60.58 $\pm 3.13 \%)$, regardless of the additives. While DMSO and methanol are cryopreserved with glucose diluent at $\mathrm{pH} 7.2$ ( $88.75 \pm 1.25$ and $82.50 \pm 4.78 \%$, respectively) gave the best results, the methyl glycol gave the best results when it is cryopreserved with glucose diluent at $\mathrm{pH} \quad 7.6$ $(70.00 \pm 7.90 \%)$ (Table 3). We determined significant interaction between cryoprotectant and extender $\mathrm{pH}$ on the post-thaw motility duration $(\mathrm{P}<0.01)$. So, 
cryoprotectants and extender $\mathrm{pH}$ were tested separately (Table 4). On Table 4, the motility duration of sperm which were cryopreserved in twelve freezing media after the thawing process is show. Cryoprotectant has a significant effect on post-thaw motility duration. Those sperms samples which are all cryopreserved in DMSO $(20.45 \pm 1.78 \mathrm{~min})$ resulted with greater post-thaw motility duration compared with methanol $(12.33 \pm 0.78 \mathrm{~min})$ and methyl glycol $(15.07 \pm 0.83 \mathrm{~min})(\mathrm{P}<0.001)$. But, there was no difference among the cryopreserved sperm with a glucose diluent at four different $\mathrm{pH}$ on post-thaw motility duration $(\mathrm{P}>0.05)$.

\section{Discussion}

Our study is the first published one about the cryopreservation process of $C$. trutta sperm. The quality of sperm after thawing process was assessed regarding the sperm mobility rate and the duration of motility at the beginning.

\section{Characteristics of Fresh Sperm}

Fresh sperm of $C$. trutta was evaluated and described. Males were utilized in this study and analysed for sperm motility rate $(85 \%)$, volume $(157 \mu \mathrm{l})$, concentration $\left(7 \times 10^{9}\right.$ spermatozoa $\left.\mathrm{ml}^{-1}\right)$ and osmolality $(294 \mathrm{mOsmol}$ $\mathrm{kg}^{-1}$ ). Those factors were all in the nominal range which was also considered for fresh sperm of different the Cyprinidae subfamily species (Lahnsteiner et al., 2000; Doğu et al., 2015; Özgür and Gürçay, 2016). It is necessary to have a better knowledge in terms of those characteristics belonged to the fresh sperm motility in order to assess the quality of sperm before the artificial reproduction in fish hatcheries and before making experiments in laboratories. For preventing the samples from contamination and also preventing the premature induction of motility because of this contamination by urine or water, fresh sperms are commonly examined before the start of experiment (Viveiros and Godinho, 2009).

\section{Cryoprotectants}

Motility percentage of sperm and the duration of motility after thawing process were both subjectively evaluated under light microscope. The three cryoprotectants tested here had a significant effect on the sperm motility $(\mathrm{P}<0.05)$ and motility duration $(\mathrm{P}<0.001)$ after thawing process. Those samples which were all cryopreserved in DMSO resulted with greater motility rate $(81 \%$ and $20 \mathrm{~min})$ compared with methanol (73\% and $12 \mathrm{~min}$ ) and methylglucol (60\% and $15 \mathrm{~min}$ ).

Table 2 Body weight and fresh sperm features of $C$. trutta

\begin{tabular}{l|ccc}
\hline \multicolumn{1}{c|}{ Features } & $\mathrm{n}$ & $\mathrm{Mean} \pm \mathrm{SD}$ & Range \\
\hline Total weight $(\mathrm{g})$ & 10 & $335.00 \pm 27.23$ & $260.00-390.00$ \\
Total length $(\mathrm{cm})$ & 10 & $32.80 \pm 0.93$ & $30.00-34.00$ \\
Spermatozoa Motility Rate $(\%)$ & 10 & $85.00 \pm 3.53$ & $70.00-90.00$ \\
Spermatozoa Motility Duration $(\mathrm{s})$ & 10 & $365.00 \pm 9.00$ & $350.00-390.00$ \\
Spermatozoa Volume $(\mu \mathrm{l})$ & 10 & $157.50 \pm 30.65$ & $100.00-220.00$ \\
Spermatozoa Concentration $\left(\mathrm{x} 10^{9} \mathrm{~mL}^{-1}\right)$ & 10 & $7.69 \pm 2.83$ & $2.30-13.35$ \\
Osmolality $(\mathrm{mOsmL} \mathrm{kg})$ & 10 & $294.75 \pm 3.47$ & $285.00-301.00$ \\
\hline
\end{tabular}

Table 3 Motility rate (mean $\pm \mathrm{SD} ; \mathrm{n}=3$ replicate straws x 10 males) of $C$. trutta sperm cryopreserved in twelve freezing media, comprising combinations of three cryoprotectants and four extenders at 4 different $\mathrm{pH}$.

\begin{tabular}{|c|c|c|c|c|}
\hline \multirow{2}{*}{ Cryoprotectants (10\%) } & \multirow{2}{*}{$\begin{array}{c}\text { Diluent } \mathrm{pH}(\text { Glucose }) \\
(80 \%)\end{array}$} & \multirow{2}{*}{$\mathrm{N}$} & \multicolumn{2}{|c|}{ Spermatozoa Motility Rate (\%) } \\
\hline & & & Mean \pm SD & Range \\
\hline \multirow{5}{*}{ DMSO } & 7.2 & 10 & $88.75 \pm 1.25^{\mathrm{a}}$ & $50.00-90.00$ \\
\hline & 7.6 & 10 & $82.50 \pm 4.78^{\mathrm{a}}$ & $50.00-90.00$ \\
\hline & 8.0 & 10 & $78.75 \pm 4.26^{\mathrm{a}}$ & $30.00-90.00$ \\
\hline & 8.4 & 10 & $75.00 \pm 6.12^{\mathrm{b}}$ & $50.00-85.00$ \\
\hline & Total & 40 & $81.25 \pm 3.21$ & $30.00-90.00$ \\
\hline \multirow{5}{*}{ Methanol } & 7.2 & 10 & $82.75 \pm 4.16^{\mathrm{a}}$ & $60.00-90.00$ \\
\hline & 7.6 & 10 & $82.59 \pm 4.18^{\mathrm{a}}$ & $60.00-90.00$ \\
\hline & 8.0 & 10 & $72.50 \pm 4.36^{\mathrm{a}}$ & $50.00-90.00$ \\
\hline & 8.4 & 10 & $57.50 \pm 4.78^{b}$ & $40.00-85.00$ \\
\hline & Total & 40 & $73.75 \pm 3.21$ & $40.00-90.00$ \\
\hline \multirow{5}{*}{ Methylglucol } & 7.2 & 10 & $65.00 \pm 6.45^{\mathrm{a}}$ & $40.00-90.00$ \\
\hline & 7.6 & 10 & $70.00 \pm 7.90^{\mathrm{a}}$ & $40.00-90.00$ \\
\hline & 8.0 & 10 & $52.50 \pm 4.78^{\mathrm{b}}$ & $30.00-90.00$ \\
\hline & 8.4 & 10 & $52.50 \pm 2.50^{\mathrm{b}}$ & $30.00-85.00$ \\
\hline & $\begin{array}{l}\text { Total } \\
\mathrm{P}<0.0\end{array}$ & 40 & $60.58 \pm 3.13$ & $30.00-90.00$ \\
\hline
\end{tabular}

a, b: Different letter superscripts indicate means that were significantly different $(\mathrm{P}<0.05)$. 
Table 4 Post-thaw motility duration (mean $\pm \mathrm{SD}$; $\mathrm{n}=3$ replicate straws $\mathrm{x} 10$ males) of $C$. trutta sperm cryopreserved in twelve freezing media, comprising combinations of three cryoprotectants and four extenders at 4 different $\mathrm{pH}$.

\begin{tabular}{|c|c|c|c|c|}
\hline \multirow{2}{*}{\multicolumn{2}{|c|}{ Cryoprosolutions }} & \multirow{3}{*}{$\frac{N}{10}$} & \multicolumn{2}{|c|}{ Post-thaw Motility Duration (min) } \\
\hline & & & Mean \pm SD & Range \\
\hline \multirow{4}{*}{ Cryoprotectants $(10 \%)$} & DMSO & & $20.45 \pm 1.78^{\mathrm{a}}$ & $11.00-32.00$ \\
\hline & Methanol & 10 & $12.33 \pm 0.78^{b}$ & $9.00-18.54$ \\
\hline & Methylglucol & 10 & $15.07 \pm 0.83^{\mathrm{b}}$ & $10.00-20.13$ \\
\hline & Total & 40 & $15.93 \pm 0.83$ & $9.00-32.00$ \\
\hline \multirow{7}{*}{ Extender $\mathrm{pH}$ (Glucose) $(80 \%)$} & & 001 & & \\
\hline & 7.2 & 10 & $18.82 \pm 1.98 \mathrm{~ns}$ & $9.00-32.00$ \\
\hline & 7.6 & 10 & $15.00 \pm 0.67 \mathrm{~ns}$ & $11.00-20.00$ \\
\hline & 8.0 & 10 & $13.33 \pm 1.00 \mathrm{~ns}$ & $10.00-19.00$ \\
\hline & 8.4 & 10 & $16.66 \pm 2.35 \mathrm{~ns}$ & $9.00-30.00$ \\
\hline & Total & 40 & $15.93 \pm 0.83 \mathrm{~ns}$ & $9.00-32.00$ \\
\hline & \multicolumn{4}{|c|}{$\mathrm{P}>0.05$} \\
\hline
\end{tabular}

a, b: Different letter superscripts indicate means that were significantly different $(\mathrm{P}<0.05$; Ns: $\mathrm{P}>0.05)$. ns: non-significant

Similar results were obtained in another Cyprinidae, when sperm motility and post-thaw motility duration were compared (Lahnsteiner et al., 2000; Akçay et al., 2004). In addition, our result conflicts with Felizardo et al (2010), who reported in Prochilodus lineatus that methanol led to a longer duration $(74 \pm 59 \mathrm{~s})$ than DMSO ( $58 \pm 4 \mathrm{~s})$. These differences could be due to adding the egg yolk to the cryoprotectants. Because, if fewer sperm cell abnormalities, for increasing the duration of motility, the methanol is used to enhance the motility duration as being used as intracellular cryoprotectant, thus, using egg yolk is a common technique as being used as extracellular cryoprotectant. Accordingly, it is recommended to use methanol as intracellular cryoproctectant and to add egg yolk as extracellular protectant while cryopreserving the Prochilodus lineatus sperm. (Felizardo et al., 2010). Besides, in comparison of the combination of glucose and methlyglycol (88\%) with DMSO (80\%) in Prochilodus lineatus, post-thaw sperm quality was significantly higher in the combination (Viveiros et al., 2009). Similarly, using glucose-methylgycol in cryopreservation of sperm resulted with the motile cells $(81 \%)$ in the biggest percentage comparing to the cryopreservation of the sperm in the DMSO (52\%) and BTSTM (Beltsville Thawing Solution Minitüb ${ }^{\mathrm{TM}}$, the medium used to preservation produced in Tiefenbach/Landshut, Germany including $80 \%$ glucose, $12.7 \%$ sodium citrate, $2.7 \%$ EDTA, $2.7 \%$ NaHCO3, $1.5 \%$ $\mathrm{KCl}, \quad 0.5 \%$ gentamycin sulfate) $(57 \%)$ in Piaractus brachypomus (Nascimento et al., 2010). As our results revealed, it could be asserted that using DMSO can be preferable than using methylglycol and methanol.

\section{Extender $\mathrm{pH}$}

The environmental $\mathrm{pH}$ has a regulatory and also indirect role and could be revealed by means of those changes occur in intracellular pH (Parrish et al., 1989; Márián et al., 1997). However, this possibility is ruled out by Márián et al. (1997) experimental finding that any changes occur relatively in $\mathrm{pH}$ of the suspending medium did not affect the intracellular $\mathrm{pH}$. The four additives $\mathrm{pHs}$ (7.2, 7.6, 8.0 and 8.4) tested in present study affected post-thaw motility rate, but did not affect post-thaw duration of motility. Similarly, Márián et al. (1997) reported that alkaline $\mathrm{pH}$ of the environment reveal any effect on the duration of motility.

Glucose is a common additive for preserving the fish sperm. Buffered additives are commonly used during the cooling process for preventing the accumulation of sperm metabolites, therefore it prevents any changes in sperm $\mathrm{pH}$ and accordingly any damages to be occurred in the sperm cells (Chen et al., 2004). By using three different additives (202, 335 and $363 \mathrm{mOsm})$ at different $\mathrm{pH}$ values (6.7, 8.2 and 6.5 respectively) in order to cryopreserving the sperm of turbot Scophthalmus maximus, best results were obtained at $\mathrm{pH}$ 8.2. For the cryopreservation of different species such as dusky grouper (Sanches et al., 2008), Brazilian flounder (Lanes et al., 2008) and fat snook sperm (Tiba et al., 2009), the same pH value is successfully used. But, in this study we had the best motility rate with DMSO at $\mathrm{pH}$ 7.2. DMSO in alkaline environment (intracellular $\mathrm{pH}$ ) may be caused to increase intracellular $\mathrm{pH}$ of spermatozoa. This situation may have led to a decrease in sperm motility. Changes in motility may be formed in a long time in developing nonphysiological changes in intracellular $\mathrm{pH}$. Hypoosmotic shock caused the intracellular $\mathrm{PH}$ become being at more alkaline values. Márián et al. (1997) reported that the alkaline $\mathrm{pH}$ of the cytoplasm could cause a decrease in the motile fraction in common carp sperm.

In addition, these differences could be due to the differences in species. Because, former studies show that the additive $\mathrm{pH}$ plays an important role for the determination of success in cryopreservation process. It is reported that the best mobility rates for common carp were found at $\mathrm{pH}$ 7-8 (Linhart and Cosson, 1997). Besides, the intracellular spermatozoa $\mathrm{pH}$ of mammals was determined as almost 6.5 using with $\mathrm{pH}$-sensitive fluorescent probes. After the in vitro capacitation, bicarbonate- containing media (at $\mathrm{pH}$ 7.4) were founds as intracellular $\mathrm{pH}>0.3$ units (Zeng et al., 1996; Babcock 1983; Florman et al., 1989; Navarro et al., 2007). When is prevented by glucose incubation, bovine sperm fail to capacitate (Parrish et al., 1989; Galantino-Homer et al., 2004). A similar situation may have occurred in these fish species. High diluent $\mathrm{pH}$ may be due to increase the intracellular $\mathrm{pH}$, so this can be lowered duration of postthaw motility. 


\section{Conclusions}

As a consequence of our study, we could assert that cryoprotectant is not the primary and essential factor in the motility and duration of motility after thawing process in $C$. trutta sperm. Post-thaw motility finding in sperm response to extender $\mathrm{pH}$, resulting in high sperm motility in DMSO and methanol at 7.2, 7.6 and $8.0 \mathrm{pH}$; in Methylglucol at 7.2 and $7.6 \mathrm{pH}$ and also cause an increase in the duration of motility.

\section{Acknowledgments}

This study has been supported by the Harran University Scientific Research Projects Coordination Unit. Project Number: 13046. We would like to express our appreciations to Prof. Ana T. M. Viveiros and her husband researcher $\mathrm{PhD}$. Marcelo C. Leal at Federal University of Lavras in Brasil. Also, we gratefully acknowledge the valuable contribution of their laboratory staff.

\section{References}

Akçay E, Bozkurt Y, Seçer S, Tekin N. 2004. Cryopreservation of mirror carp semen. Turk. J. Vet. Anim. Sci., 28: 837-843.

Alavi SMH, Cosson J. 2005. Sperm motility in fishes. (I) Effects of temperature and pH: a review. Cell Biol. Int., 29: 101-11.

Alavi SM., Cosson J, Kazemi R. 2006. Semen characteristics in Acipenser persicus in relation to sequential stripping. J. Appl. Ichthyol., 22: 400-405.

Alavi SMH, Cosson J. 2006. Sperm motility in fishes. (II) Effects of ions and osmolality: a review. Cell Biol. Int., 30: $1-14$.

Alavi SMH, Rodina M, Policar T, Linhart O. 2009. Relationship between semen characteristics and body size in Barbus barbus L. (Teleostei: Cyprinidae) and effects of ions and osmolality on sperm motility. Comp Biochem Physiol A., 153: 430-437.

Babcock DF. 1983. Examination of the intracellular ionic environment and of ionophore action by null point measurements employing the fluorescein chromophore. J Biol Chem., 258 (10): 6380-9.

Babiak I, Glogowski J. 1998. Cryopreservation of sperm from asp Aspius aspius. Prog Fish Cult., 60: 146-148.

Babiak I, Glogowsky J, Brzuska E, Szumiec J, Adamek J. 1995. Cryopreservation of sperm of common carp, Cyprinus carpio. Aqua.. Res., 28: 567-571.

Baker TT, Timmons SL. 1991. Precision of ages estimated from five bony structures of Arctic char (Salvelinus alpinus) from the Wood River System, Alaska. Can J Fish Aqua Sci., 48: 1007-14.

Billard R, Cosson J, Crim LW, Suquet M. 1995. Sperm physiology and quality. In: Bromage NR, Roberts RJ, editors. Brood stock management and egg and larval quality. Blackwell Science, 25-52.

Billard R, Cosson J, Perchec G, Linhart O. 1995. Biology of sperm and artificial reproduction in carp. Aquac., 124: 95112.

Bozkurt R, Şevik R, Ünlü E. 1999. Atatürk Baraj Gölü'nde yaşayan Capoeta trutta (Heckel, 1843)'nın üreme özellikleri üzerine bir araştırma. Harran Üniversitesi Ziraat Fakültesi Dergisi, 3: 11-20.

Brown GG, Brown LD. 2000. Cryopreservation of sperm of striped bass and white bass. In: Tiersch TR, Mazik PM, ediors. Cryopreservation in aquatic species. Baton Rouge: Wor. Aqua. Soc., p. 130-137.
Canpolat Ö, Çalta M. 2013. Reproduction properties of Capoeta trutta (Heckel, 1843) from Pertek Region of Keban Dam Lake. Turkish Journal of Science and Technology, 8: 6368.

Chen S, Ji XS, Yu GC, Tian YS, Sha XZ. 2004. Cryopreservation of sperm from turbot (Scophthalmus maximus) and application to large-scale fertilization. Aquac., 236: 547-556.

Chugunova N.I. 1963 - Age and growth studies in fish - Israel Prog. Sci. Transl. No: 610, Natl. Sci. Found Washington, D.C. $132 \mathrm{pp}$.

Cognie F, Billard R, Chao NH. 1989. Freezing of the milt of the common carp, Cyprinus carpio. J. Appl. Icht., 5: 165-176.

Coser AM, Godinho H, Riberio D. 1984. Cryogenic preservation of spermatozoa from Prochilodus scrofa and Salminus maxillosus. Aquac., 37: 387-390.

Cosson MP, Cosson J, Billard R. 1991. cAMP dependence of movement initiation in intact and demembraned trout spermatozoa. In: Scott AP, Sumpter JP, Kime DE, Rolfe MS, editors. Proceedings of fourth international symposium on reproductive physiology of fish. University of East Anglia. Norwich. UK., p. 262-264.

DeGraaf JD, Berlinsky DL. 2004. Cryogenic and refrigerated storage of rainbow smelt Osmerus mordax spermatozoa. J. Wor. Aquac. Soc., 35: 209-216.

Doğu, Z., Şahinöz, E., Aral, F., Yüksel AY. 2015. Atatürk Baraj Gölü'ndeki erkek Capoeta trutta (H., 1843) balıklarınınbazı spermatolojik özelliklerinin belirlenmesi. GAP VII. Tarım Kongresi, 28 Nisan-1 Mayıs 2015 Şanlıurfa, 694.

Duman, E., 2004. Keban Baraj Gölü'nde yaşayan Capoeta trutta (Heckel, 1843)'nın üreme biyolojisi, F.Ü. Fen ve Mühendislik Bilimleri Dergisi, 16(1): 145-150.

Düşükcan M, Çalta M. 2012. Capoeta trutta (Heckel, 1843)'nın Keban, Karakaya ve Atatürk Baraj Gölleri'ndeki populasyonlarının üreme dönemlerinin karşılaştırılması. Fırat Üniv. Fen Bilimleri Dergisi, 24: 57-61.

Eroğlu M, Şen D. 2017. Reproduction cycle and monthly alteration of serum testosterone, estradiol and cholesterol in Capoeta trutta (Heckel, 1843). Journal of Scientific and Engineering Research, 4(4): 99-105.

Felizardo VO, Mello RA, Murgas LDS, Andrade ES, Drumond MM, Rosa PV. 2010. Effect of cryopreservant combinations on the motility and morphology of curimba (Prochilodus lineatus) sperm. Anim. Reprod. Sci., 122: 259-263.

Florman HM, Tombes RM, First NL, Babcock DF. 1989. An adhesion-associated agonist from the zona pellucida activates $\mathrm{G}$ protein-promoted elevations of internal $\mathrm{Ca}^{2+}$ and $\mathrm{pH}$ that mediate mammalian sperm acrosomal exocytosis. Dev. Biol., 135 (1): 133-46.

Galantino-Homer HL, Florman HM, Storey BT, Dobrinski I, Kopf GS. 2004. Bovine sperm capacitation: assessment of phosphodiesterase activity and intracellular alkalinization on capacitation-associated protein tyrosine phosphorylation. Mol. Reprod. Dev., 67(4): 487-500.

Kalkan E. 2008. Growth and reproduction properties of Capoeta trutta (Heckel,1843) in Karakaya Dam Lake. Turk J Zoology, 32: 1-10.

Koldras M, Bieniarz K. 1987. Cryopreservation of carp sperm. Pols Arch Hydrobiol., 34: 125-134.

Kurokura H, Hirano R, Tomita M, Iwahashi M. 1984. Cryopreservation of carp sperm. Aquac., 37: 267-273.

Lahnsteiner F, Berger B, Horvath A, Urbanyi B, Weismann T. 2000. Cryopreservation of spermatozoa in cyprinid fishes. Therio., 54: 1477-1498.

Lakra WS, Krishna G. 1997. Preliminary trials for cryopreservation of spermatozoa of selected carps and catfishes. Ind. J. Anim Sci., 67: 90-92.

Lanes CFC, Okamoto M, Cavalcanti PV, Colares T, Campos VF, Deschamps JC, Robaldo RB, Marins LF, Sampaio LA. 2008. Cryopreservation of Brazilian flounder (Paralichthys orbignyanus) sperm. Aquac., 275: 361-365. 
Linhart O, Cosson J, Mims SD, Rodina M, Gela D, Shelton WL. 2003. Effects of ions on the motility of fresh and demembranate spermatozoa of common carp (Cyprinus carpio) and paddlefish (Polyodon spathula). Fish Phys. Bioch., 28: 203-205.

Linhart O, Cosson J. 1997. Cryopreservation of carp (Cyprinus carpio L.) spermatozoa: the influence of external $\mathrm{K}+$ and $\mathrm{Na}+$ on post-thaw motility. Pol. Arch. Hydro., 44 (1-2): 275-279.

Linhart O, Liehman P, Rab P. 1988. The first results in freezing of carp semen. Bull. Vurh Vod., 24: 3-13.

Linhart O, Rodina M, Cosson J. 2000. Cryopreservation of sperm in common carp Cyprinus carpio: sperm motility and hatching success of embryos. Cryo., 41: 241-250

Lubzens E, Daube N, Pekarsky I, Magnus Y, Cohen A, Yusefovich F, Feigin P. 1997. Carp (Cyprinus carpio L.) spermatozoa cryobanks - strategies in research and application. Aquac., 155: 13-30.

Márián T, Krasznai Z, Balkay L, Emri M, Trón L.1997. Role of Extracellular and Intracellular $\mathrm{pH}$ in Carp Sperm Motility and Modifications by Hyperosmosis of Regulation of the Na1/H1 Exchanger. Cyto., 27: 374-382.

Morisawa M, Suzuki K. 1980. Osmolality and potassium ions: their roles in initiation of sperm motility in teleosts. Sci., 210: 114-115.

Nascimento, AF, Maria AN, Pessoa NO, Carvalho MAM, Viveiros ATM. 2010. The success of out-of-season sperm cryopreserved in different freezing media of the Amazonian freshwater fish pirapitinga (Piaractus brachypomus). Anim. Reprod. Sci., 118: 324-329.

Navarro B, Kirichok Y, Clapham DE. 2007. KSper, a pHsensitive $\mathrm{K}+$ current that controls sperm membrane potential Proc. Natl. Acad. Sci., 104 (18): 7688-7692.

Ozdemir N, Kabukcu A. 1983. Studies on Capoeta trutta (Heckel, 1843) from Keban Dam Lake (Elazig) length, weight, and reproductive period. F.U. Vet. Fak. Der., 35: 1522.

Özgür, M. E., Gürçay S. 2016. Computer assisted sperm analysis (CASA) of spermatozoa motility parameters on wild caught Capoeta trutta (heckel, 1843) in the Euphrates river, 2nd International Congress on Applied Ichthyology \& Aquatic Environment, 10 - 12 November 2016, Messolonghi, Greece.

Parrish JJ, Susko-Parrish JL, First NL. 1989. Capacitation of bovine sperm by heparin: inhibitory effect of glucose and role of intracellular pH. Biol Reprod., 41(4): 683-99.

Polat N. 1987. Age determination of Capoeta trutta (Heckle, 1843) in Keban Dam Lake. Tur. J. Zool., 11: 155-160.

Sanches EG, Oliveira IR, Serralheiro PCS. 2008. Criopreservação do sêmen da garoupa-verdadeira Epinephelus marginatus. Bioikos., 22: 81-90.
Sansone G, Fabbrocini A, Ieropoli S, Langellotti A, Occidente M, Matassino D. 2002. Effects of extender composition, cooling rate, and freezing on the motility of sea bass (Dicentrarchus labrax L.) spermatozoa after thawing. Cryo., 44: 229-239.

Şevik R. 1993. Asağı Fırat sularının doğal kalitesi üzerine Atatürk Barajının etkileri ve su ürünleri açısından değerlendirilmesi, Güneydogu Anadolu Bölgesi $I$. Hayvancılık Kongresi, 12-15 Mayıs, Şanlıurfa, 362-374.

Şevik R. 1995. Aşağı Fırat Suları'nda yaşayan Capoeta trutta (Heckel, 1843)'nın büyüme durumu ve üreme özellikleri üzerine araştırmalar. I. Su Ürünleri Sempozyumu, Atatürk Üniversitesi Ziraat Fak. Su Ürünleri Bölümü, Erzurum, 172200.

Stoss J. 1983. Fish gamete preservation and spermatozoan physiology. In: Hoar WS, Randall DJ, Donaldson EM, editors. Fish Physiology $1 X$ B. New York: Academic Press, 305-350.

Tiba RM, Oliveira IR, Serralheiro PCS, Ostini S. 2009. Diluentes e proporções sêmen: diluente na crioconservação do sêmen do robalo-peva Centropomus parallelus. Bol. Inst. Pesca., 35: 99-110.

Tiersch TR, Figiel CR, Wayman WR, Williamson JH, Carmichael GJ, Gorman O. 1998. Cryopreservation of sperm of the endangered razorback sucker. Trans. Am. Fish. Sot., 127: 95-104.

Ünlü E. 1991. A study on the biological characteristics of Capoeta trutta (Heckel, 1843) living in the Tigris River, Turkey. Tur. J. Zool., 15: 22-38.

Viveiros ATM, Orfão LH, Maria AN, Allaman IB, 2009. A simple, inexpensive and successful freezing method for curimba Prochilodus lineatus (Characiformes) semen. Anim. Reprod. Sci., 112: 293-300.

Viveiros ATM, Godinho HP, 2009. Sperm quality and cryopreservation of Brazilian freshwater fish species: a review. Fish Phys. Bioch., 35: 137-150.

Wildt DE, Comizzoli P, Pukazhenthi B, Songsasen N. 2010. Lessons from biodiversity - the value of nontraditional species to advance reproductive science, conservation, and human health. Mol. Reprod. Dev., 77: 397-409.

Withler FC. 1982. Cryopreservation of spermatozoa of some fresh water fishes cultured in south and southeast Asia. Aquac., 26: 395-398.

Yapalak S, Solak K, Oymak SA. 1997. Atatürk Baraj Gölü (Fırat)'nde yaşayan Capoeta trutta (Heckel, 1843)'nın üreme özellikleri üzerine bir araştırma. IX. Ulusal Su Ürünleri Sempozyumu, Eğirdir - Isparta, 182-192.

Zeng Y, Oberdorf JA, Florman HM. 1996. pH regulation in mouse sperm: identification of $\mathrm{Na}(+)-, \mathrm{Cl}(-)-$, and $\mathrm{HCO} 3(-)-$ dependent and arylaminobenzoate-dependent regulatory mechanisms and characterization of their roles in sperm capacitation. Dev Biol., 173 (2): 510-20.

Zhang X, Liu Y. 1991. Study of cryopreservation of fish spermatozoa. Acta Sci. Nat. Univ. Norm. Hun., 14: 255-259. 